\title{
PENDIDIKAN MELAYU DAN AGAMA DI JOHOR BAHRU, 1857-1957
}

\author{
Arba'iyah Mohd Noor ${ }^{1, *}$ \\ ${ }^{1}$ Jabatan Sejarah, Fakulti Sastera dan Sains Sosial, Universiti Malaya, 50603 Kuala Lumpur, MALAYSIA.
}

\begin{abstract}
Before the arrival of the British, the Malays in Johor had their own educational pattern based on Islamic education and al-Quran. This traditional educational institution continued without changing its basic structure even after the British presence in the state of Johor. Thus, this paper will discuss the development of Malay and religious education in Johor Bahru from 1857 to 1957. This paper will begin with a description of the background of Malay and religious education in Johor. In addition, this paper will also focus on the changes that have been made by the government during this period. The paper will look at the roles and strategies of the Malay community in advancing the education of the Malays in Johor Bahru at that time. This qualitative study uses the library research approach by examining several primary sources such as the Johor Annual Report from 1910-1915, Education in Johore, 1928-1933, Penyata Jabatan Agama Johor 1932, Penyata Sekolah-Sekolah Agama Johor dan Daerahnya bagi Tahun 1939 dan 1951 available at the National Archives of Malaysia (Johor Branch) as well as some secondary sources such as books and theses.
\end{abstract}

Keywords: Education; Religious and Malay Schools; Johor Bahru; Change; Roles

* Corresponding author: arbaiyah@um.edu.my

eISSN: 2636-9257 CPusat Dialog Peradaban Universiti Malaya, 2021

DOI: https://doi.org/10.22452/PERADABAN.vol14no1.2 


\begin{abstract}
Abstrak
Sebelum kedatangan British, masyarakat Melayu di Johor mempunyai corak pendidikan tersendiri berdasarkan asas pendidikan Islam dan al-Quran. Institusi pendidikan tradisional ini diteruskan tanpa merubah struktur asasnya walaupun setelah kehadiran British ke negeri Johor. Justeru, makalah ini akan membincangkan mengenai perkembangan pendidikan Melayu dan agama di Johor Bahru dari 1857-1957. Makalah ini akan dimulakan dengan huraian mengenai latar belakang pendidikan Melayu dan agama di Johor. Di samping itu, makalah ini akan turut memfokuskan tentang perubahan yang telah dilakukan oleh pihak kerajaan dalam tempoh tersebut. Selain itu, makalah ini akan melihat peranan dan strategi masyarakat Melayu pelbagai lapisan dalam memajukan pendidikan masyarakat Melayu di Johor Bahru pada ketika itu. Kajian kualitatif ini menggunakan pendekatan kajian perpustakaan dengan meneliti beberapa sumber primer seperti Johor Annual Report dari 1910-1915, Education in Johore, 1928-1933, Penyata Jabatan Agama Johor 1932, Penyata Sekolah-Sekolah Agama Johor dan Daerahnya bagi Tahun 1939 dan 1951 yang terdapat di Arkib Negara Malaysia Cawangan Johor selain sumber sekunder berbentuk buku dan tesis.
\end{abstract}

Kata Kunci: Pendidikan; Sekolah Melayu dan Agama; Johor Bahru; Perubahan; Peranan

\title{
Pengenalan
}

Secara umumnya masyarakat Melayu termasuk di Johor telah terdedah kepada sistem pendidikan Islam sejak dari awal kedatangan Islam ke rantau ini. Jika dilihat dari segi sejarah, Johor telah menjadi tumpuan para ulama', ilmuan dan cendiakawan dari pelbagai tempat untuk mengajar masyarakat tempatan terutama ilmu agama sejak abad ke-19 lagi. Tradisi ini telah diteruskan oleh ulama' dan cendiakawan tempatan dalam usaha mengembangkan ilmu agama di Johor walaupun setelah kemasukan British di Johor. Pendidikan agama secara tidak formal ini dijalankan di masjid, surau, rumah tuan guru atau imam yang kemudiannya berkembang menjadi pondok dan madrasah apabila pelajar semakin ramai. Struktur dan kurikulum ini tidak banyak bezanya di mana-mana daerah atau kawasan lain yang didatangi ulama Islam. Secara umumnya pendidikan agama yang diberikan kepada kanak-kanak lelaki dan perempuan adalah seawal usia enam hingga tujuh tahun kerana mereka mudah dibentuk dalam usia sebegini. Mereka diajar mengenal huruf-huruf al-Quran, mengeja, menulis menggunakan abjad jawi, menghafal dan membaca al-Quran.

Setelah kedatangan British, sistem vernakular telah diperkenalkan di sekolah Inggeris, Melayu, Cina dan Tamil. Walaupun peringkat awal mendapat tentangan terhadap pendidikan vernakular oleh masyarakat Melayu, namun akhirnya sistem pendidikan Melayu ini telah diterima oleh masyarakat Melayu pada awal abad ke-20. Namun, terdapat kritikan oleh kerajaan British terhadap sekolah Melayu dan agama yang dijalankan di negeri Johor. Antara kritikan tersebut adalah dari segi kehadiran guru dan 
muridnya yang tidak menepati masa, bangunan yang tidak terurus, kurang pemantauan dan pemeriksaan, silibus yang tidak tersusun, kemudahan fizikal yang uzur dan sebagainya (Education in Johore, 1928-1933). Memandangkan terdapat dakwaan terhadap kelemahan dalam sistem pendidikan Melayu dan agama di Johor, maka makalah ini akan membincangkan tentang sejauh mana benarnya dakwaan tersebut? Adakah kerajaan Johor hanya memberi perhatian terhadap sekolah Inggeris sahaja? Bagaimana bentuk perubahan dalam pendidikan Melayu dan agama yang dilakukan dan peranan tokoh dalam memperkasa usaha tersebut?

\section{Latar Belakang Awal Pendidikan Agama dan Melayu di Johor}

Pertumbuhan dan pentadbiran sekolah Melayu wujud di Johor sebelum tahun 1883. Antara sekolah Melayu pertama di Johor Bahru yang dibina pada 1878 ialah Sekolah Melayu Kampung Kandang Ayam. Sekolah ini terletak di perkarangan kawasan istana besar Johor Bahru dan berdekatan dengan bangunan pengawal istana. Sekolah ini merupakan sebuah bangsal panjang menggunakan atap dan papan dan kemudiannya dipindahkan ke Balai Bukit Zaharah kerana di kawasan itu akan dibina Istana Semayam. Sekolah sementara telah dibina di kaki Bukit Timbalan sebelum istana baru disiapkan untuk dipindahkan semula sekolah tersebut. Disebabkan istana digunakan oleh kerabat diraja, Sekolah Melayu Johor Bahru kemudian terus berpindah-pindah tempat. Pada mulanya menggunakan rumah Dato' Bentara Dalam, Dato' Mohd. Ibrahim bin Abdullah Munsyi yang dikenali sebagai Sekolah Melayu Seri Kopi (Sekolahsekolah Johor, tanpa tahun). ${ }^{1}$

Apabila kerajaan menubuhkan sistem pentadbiran pendidikan pada 1883, telah wujud 5 buah sekolah di Negeri Johor iaitu Sekolah Melayu Johor Bahru (guru besarnya Encik Mohd Khalid bin Abdullah); Sekolah Melayu Padang, Muar (guru besarnya Encik Daud bin Mohamad); Sekolah Melayu Tanjong Surat; Sekolah Melayu Pengerang (guru besarnya Tuan Layman) dan English School Johor Bahru (guru besarnya H.G. Yzelmann) (Sekolah-sekolah Johor, tanpa tahun). Memandangkan pertambahan jumlah sekolah Melayu, Inggeris, pertanian dan agama selepas itu, maka Jabatan Pelajaran ditubuhkan menjelang 1885. Pada 1887, terdapat penyusunan semula pentadbiran kerajaan dan jawatan ketua Jabatan Pelajaran telah ditukar kepada Yang Dipertua Jabatan Pelajaran. Datuk Bentara Dalam Muhammad Ibrahim Munsyi selaku Yang Dipertua Jabatan Pelajaran telah dibantu oleh 12 orang Ahli Jawatankuasa Pelajaran. Setelah Undang-undang Tubuh Kerajaan Johor diperkenankan oleh Sultan Abu Bakar, Jabatan Agama dan Pelajaran Negeri Johor telah diwujudkan pada 1895. Ibrahim Munsyi melepaskan Jabatan Pelajaran kepada Ungku Mohd Khalid yang dilantik sebagai Yang Dipertua Jabatan Agama dan Pelajaran Johor yang pertama (Kamdi Kamil, 2018). Pendidikan agama dan Melayu terus berkembang di bawah

\footnotetext{
${ }^{1}$ Pada 1934, sekolah ini dirobohkan kerana rancangan membina sebuah sekolah baru dan digantikan di rumah Dato' Mohamad bin Mabob dengan nama Sekolah Melayu Saujana. Apabila kawasan Bukit Saujana hendak dibina taman perumahan bagi kakitangan kerajaan, sekolah ini dipindahkan semula ke bangunannya sendiri pada 1935 dengan nama Sekolah Melayu Ayer Molek, Johor Bahru.
} 
pemerintahan Sultan Ibrahim (1895-1959). Sehingga 1910, terdapat 37 buah sekolah Melayu yang diurus oleh inspektor Melayu dan jumlah pelajar mendaftar ialah 2529 orang (Annual Report Johor, 1910).

Selain pendidikan Melayu, pendidikan Inggeris telah mula menjadi penting dengan dibiayai oleh kerajaan British pada tahun 1890-an. Tujuan penubuhan sekolah Inggeris adalah untuk memberi pendidikan Inggeris kepada penduduk tempatan terutama golongan bangsawan dan elit istana serta melatih mereka sebagai tenaga kerja untuk berkhidmat dengan jabatan kerajaan. Walau bagaimanapun sehingga 1910, hanya sebuah sekolah Inggeris terletak di Johor Bahru didirikan berada di bawah kelolaan Mr. J Robert yang sebelum ini menguruskan The King Edwards School, Taiping. Beliau telah memulakan tugas di Johor bermula Ogos 1910 (Annual Report Johor, 1910). Sukatan pelajaran di sekolah Melayu dan Inggeris secara umumnya serupa walaupun kandungan dan orentasinya sedikit berbeza iaitu menekankan kebolehan membaca, menulis dan mengira, matapelajaran Ilmu Alam, Tawarikh, Ilmu Kesihatan, Pengetahuan Am, Senaman dan Permainan serta Bercucuk Tanam (Rahimah Abdul Aziz \& Rahmat Saripan, 2002). Ketika ini sekolah Inggeris di Johor Bahru diselia oleh Mr. C. M Philips yang merupakan Pengarah Pelajaran Negeri-negeri Selat dan juga pengetua Raffles Institution (Annual Report Johor, 1912).

Pada 1911, Penasihat British telah mencadangkan supaya dibina sekolah berasrama seperti Kuala Kangsar Malay College di negeri Johor. Tujuannya supaya dapat memberi pendedahan awal dan latihan bahasa Inggeris kepada pelajar bermula dari awal sebelum diserapkan ke jawatan dalam kerajaan. Ini kerana pendidikan Inggeris yang diajar di sekolah masih berada di tahap yang rendah lebih-lebih lagi mereka menghadapi kekurangan tenaga pengajar ketika itu. Pada masa yang sama pejabatpejabat kerajaan pula berhadapan dengan masalah kerani yang tidak begitu fasih dalam berbahasa Inggeris. Oleh itu, bermula tahun 1913, langkah untuk pemerkasana Sekolah Inggeris di Johor telah dilakukan. Seramai 256 orang pelajar memasuki sekolah Inggeris pada 1913 di dua buah sekolah di Johor Bahru (Annual Report Johor, 1913).

Kemudian tertubuhnya Bording School House untuk menempatkan 50 orang pelajar, Guru Besar dan 4 orang pembantu yang dikenali sebagai English Assistant Manager dari England bagi menguruskan sekolah di Johor Bahru dan Muar. Guru besar turut dihantar ke Sekolah Inggeris Harian di Johor Bahru bagi sekolah yang melebihi 300 orang pelajar lelaki. Namun jumlah pelajar ke asrama masih rendah walaupun ditanggung oleh kerajaan. Ini adalah kerana larangan ibu bapa mendaftar anak-anak mereka ke sekolah asrama kerana kebanyakan mereka kurang pengetahuan tentang kedudukan sekolah berasrama. Mr. H. H. Marrison melaporkan bahawa guru di sekolah berasrama berhadapan kesukaran mencari guru yang layak dan menguatkuasa peraturan kehadiran pelajar dengan lebih tegas lagi (Annual Report Johor, 1914).

Pada penghujung tahun 1914, seramai 8 org pelajar dari Johor Bahru telah menduduki The Straits Settlement VII Standard Examination dan 4 daripada pelajar tersebut telah 
lulus dan mendapat sijil. Walaupun bilangan pelajar di sekolah berasrama di Johor Bahru merosot dan jumlah lulus juga sedikit pada 1914, namun, sekolah asrama masih dikekalkan kerana Guru Besarnya yakin prestasi pelajar sedia ada akan meningkat setelah mereka berada di asrama selama dua ke tiga tahun (Annual Report Johor, 1910; Annual Report Johor, 1914; Annual Report Johor, 1915).

Jadual 1: Jumlah pelajar di sekolah berasrama dan sekolah harian di Johor Bahru 1914. (Sumber: Annual Report Johor, 1914)

\begin{tabular}{cccc}
\hline Jenis Sekolah & $\begin{array}{c}\text { Pendaftaran } \\
\text { (anggaran) }\end{array}$ & $\begin{array}{c}\text { Kehadiran } \\
\text { (anggaran) }\end{array}$ & Bilangan guru. \\
\hline $\begin{array}{c}\text { Sekolah } \\
\text { Berasrama/Boarding } \\
\begin{array}{c}\text { School (JB) } \\
\text { Sekolah Harian/School } \\
\text { day (JB) }\end{array}\end{array}$ & 23 & 18 & 2 \\
\hline
\end{tabular}

Di samping itu, Johor merupakan antara negeri yang juga memberi perhatian sepenuhnya kepada pendidikan untuk kanak-kanak perempuan pada awal abad ke-20. Terdapat tiga buah Sekolah Melayu untuk pelajar perempuan dan mereka turut diajar pendidikan Islam dan pengajian al-Quran di sekolah tersebut (Annual Report Johor, 1915).

Namun, jumlah pelajar perempuan masih rendah ketika ini kerana kurangnya kesedaran dalam kalangan ibubapa terhadap pendidikan untuk anak-anak perempuan dan galakan lebih diberikan kepada anak lelaki. Annual Report Johor bagi tahun 1916 dan 1917 menunjukkan peningkatan jumlah pelajar lelaki berbanding pelajar perempuan di beberapa buah sekolah vernakular di Johor seperti berikut:

Jadual 2: Jumlah sekolah, staf dan pelajar lelaki dan perempuan di sekolah-sekolah Melayu di Johor, 1916-1917. (Sumber: Diubahsuai daripada Annual Report Johor, 1916 dan Annual Report Johor, 1917)

\begin{tabular}{ccccccccc}
\hline $\begin{array}{c}\text { Sekolah } \\
\text { Vernakular }\end{array}$ & \multicolumn{2}{c}{ Jumlah Sekolah } & \multicolumn{2}{c}{ Jumlah Staf } & \multicolumn{2}{c}{$\begin{array}{c}\text { Pendaftaran } \\
\text { (anggaran) }\end{array}$} & \multicolumn{2}{c}{$\begin{array}{c}\text { Kehadiran } \\
\text { (anggaran) }\end{array}$} \\
\cline { 2 - 9 } & 1916 & 1917 & 1916 & 1917 & 1916 & 1917 & 1916 & 1917 \\
Lelaki & 61 & 61 & 94 & 95 & 2890 & 3104 & 2134 & 2297 \\
Perempuan & 5 & 5 & 6 & 6 & 206 & 199 & 160 & 130 \\
\hline
\end{tabular}

Walaupun demikian, sekolah vernakular terus berkembang dan jumlah pelajarnya semakin meningkat. Pada tahun 1920-30-an, Johor terus menunjukkan perkembangan dalam pendidikan untuk kanak-kanak perempuan menerusi penubuhan Sekolah Perempuan Kampung Baru, Sekolah Perempuan Bukit Senyum, Sekolah Perempuan Bandar Segamat, Sekolah Perempuan Bandar Kluang dan Sekolah Perempuan Bandar Tangkak. Fokus pembelajaran di sekolah perempuan ini sama seperti sekolah lelaki yang lain cuma terdapat beberapa penambahan bidang yang berkaitan dengan wanita seperti jahitan, kesihatan, masakan dan mendidik anak. 


\section{Perubahan Pendidikan Melayu dan Agama di Johor Bahru awal abad ke-20}

Secara umumnya pada awal abad ke-20 telah berlaku peningkatan jumlah sekolah dan pelajar sama ada lelaki dan perempuan di sekolah Melayu dan Inggeris. Namun, ketika ini berlaku pula penurunan jumlah pelajar lelaki dan perempuan bagi sekolah agama di Johor antara tahun 1917 dan 1918 seperti berikut:

Jadual 3: Jumlah sekolah, staf dan pelajar lelaki dan perempuan di sekolah agama di Johor, 1917-1918. (Sumber: Diubahsuai daripada Annual Report Johor, 1917 dan Annual Report Johor, 1918)

\begin{tabular}{ccccccccc}
\hline $\begin{array}{c}\text { Sekolah } \\
\text { Agama }\end{array}$ & Jumlah Sekolah & Jumlah Staf & \multicolumn{2}{c}{$\begin{array}{c}\text { Pendaftaran } \\
\text { (anggaran) }\end{array}$} & \multicolumn{2}{c}{$\begin{array}{c}\text { Kehadiran } \\
\text { (anggaran) }\end{array}$} \\
\cline { 2 - 9 } & 1917 & 1918 & 1917 & 1918 & 1917 & 1918 & 1917 & 1918 \\
Lelaki & 11 & 12 & 16 & 16 & 545 & 526 & 393 & 355 \\
Perempuan & 3 & 3 & 3 & 3 & 99 & 92 & 66 & 60 \\
\hline
\end{tabular}

Hal ini mungkin berlaku berikutan pembukaan lebih banyak sekolah Inggeris di Johor Bahru dan beberapa daerah lain kerana kerajaan British merasakan keluaran sekolah Inggeris lebih berpotensi dan boleh memenuhi keperluan dalam pentadbiran kerajaan berbanding keluaran sekolah agama. Memandangkan jumlah pelajar di sekolah agama semakin merosot, maka kerajaan Johor telah memainkan peranan aktif dalam membawa perubahan dalam pendidikan Melayu dan membangunkan pendidikan berteraskan Islam ketika ini.

Perlembagaan Johor telah meletakkan Islam sebagai agama rasminya. Selaras dengan itu, maka kerajaan negeri telah berusaha memperkasakan pendidikan agama dan tetap mengekalkan sistem persekolahan agama walaupun banyak sekolah aliran Inggeris dibangunkan kerana dilihat lebih ekonomik. Matlamat Jabatan Agama Islam negeri Johor ialah memberi perhatian serius terhadap pertumbuhan sekolah agama dan aliran Arab. Pada 1901, jabatan baru telah ditubuhkan dengan gabungan Jabatan Agama dan Pelajaran yang diketuai oleh Yang Di Pertua atau Presiden. Namun, gabungan Jabatan Agama dan Pelajaran ini berpisah pada 1906 dan berjalan secara berasingan seperti sebelum 1895 (Rahimah Abdul Aziz \& Rahmat Saripan, 2002). Bahagian Pertama ialah Bahagian Pelajaran Inggeris manakala Bahagian Kedua ialah Bahagian Pelajaran Melayu yang ditugaskan juga mengawasi sekolah Melayu dan sekolah agama. Ketua bahagian Pelajaran Melayu dikenali sebagai Pemeriksa Sekolah-sekolah Melayu Johor (Kamdi Kamil, 2018).

Pendidikan agama di Johor kemudiannya berkembang dalam bentuk pengajian alQuran atau juga disebut Sekolah Qur'an. Sekolah yang mirip sekolah pondok di Kelantan, Pattani dan Sumatera ini telah dibina di Kukup, Pontian. Para pelajar lelaki yang menyertai sekolah ini adalah lebih kurang 40-50 orang dan tiada had umur dan syarat kemasukan yang ditetapkan oleh kerajaan. Gurunya pula berasal dari luar dengan elaun yang dibayar oleh kerajaan. Apabila pelajarnya semakin ramai, maka sekolah ini terpaksa menumpang di sekolah Melayu. Selain itu, terdapat sekolah al-Kitab di Johor 
yang berasal daripada Sekolah al-Quran. Sekolah al-Quran dan Kitab yang merupakan institusi formal dalam pendidikan Islam bergabung dalam sebuah bangunan yang terdiri daripada kelas darjah satu hingga empat. Murid Sekolah Kitab menggunakan kaedah pembacaan beberapa buah kitab selain menghafaz Muqadam, membaca Quran dengan hukum tajwid secara berperingkat dan mempelajari bacaan dan mengalunkan kitab Berzanji Antara kitab terkenal yang digunakan oleh generasi pertama sebelum merdeka ialah Matla'al Badrin wa Majma' al-Bahrain dan Hidayatus-Salikin (Kamdi Kamil, 2018).

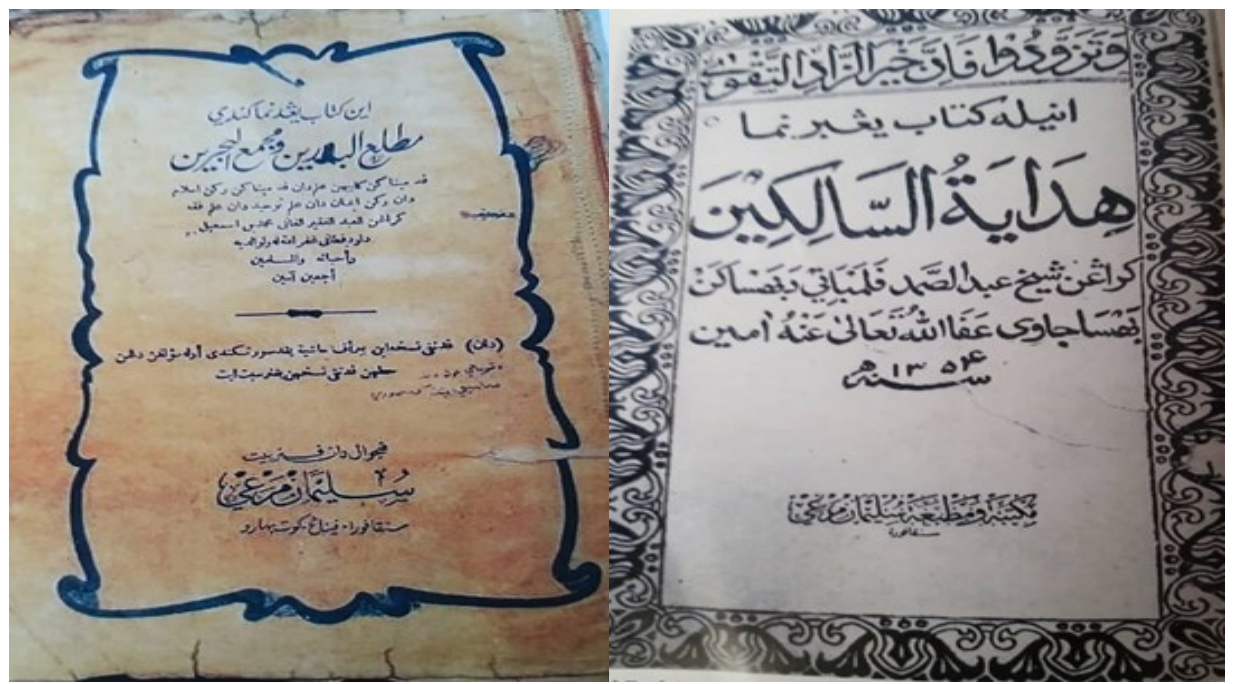

Rajah 1: Kitab Matla'al Badrin wa Majma' al-Bahrain dan Hidayatus-Salikin (Sumber: Kamil, 2018).

Selain sekolah yang ditubuhkan oleh kerajaan, terdapat juga sekolah swasta yang didirikan oleh individu tertentu di Johor Bahru seperti Madrasah Abdul Aziz Al-Shinie di Johor Bahru, Kuliah al-Attas dan Madrasah al-Attas al-Arabiah di Johor Bahru yang bermula sejak 1912 atau 1914. Madrasah ini merupakan institusi pengajian tinggi dalam bidang agama Islam yang menerima pelajar dari dalam dan luar negeri Johor. Namun, sekolah-sekolah ini telah diletakkan di bawah penyeliaan Jabatan Agama Johor pada 1932 kerana berpotensi menarik ramai penuntut di kawasan itu (M.A. Fawzi Basri, 1978; Penyata Jabatan Agama Johor,1932). Galakan dan peluang terhadap anakanak Johor untuk melanjutkan pelajaran ke luar negara seperti di Kaherah dan Beirut turut disediakan oleh Kerajaan Johor. Buktinya, biasiswa sebanyak $\$ 500$ setahun pernah diberikan kepada Muhammad Amin Harun yang menuntut di Madrasah alAkkadin dan Abdul Jalil Hassan yang menuntut di Universiti al-Azhar.

Kemunculan pentadbiran British sedikit sebanyak telah mempengaruhi pendidikan agama yang kemudiannya bersifat formal melalui penubuhan sekolah-sekolah Melayu. Pada 1918, sekolah al-Kitab telah diubah menjadi Sekolah Agama Petang Kerajaan Johor (SAPKJ) atas titah Sultan Ibrahim dengan Bahasa Melayu sebagai bahasa pengantar supaya mudah difahami. Namun, tidak semua daerah menerima pendidikan SAPKJ secara serentak kerana bergantung kepada penubuhan sekolah Melayu, jumlah 
guru dan peruntukan kewangan daripada kerajaan negeri. SAPKJ yang disifatkan sebagai institusi formal dengan tambahan matapelajaran Muamalat, Munakahat, Faraid, Akhlak, Tulisan Jawi dan Bahasa Arab telah dilaksanakan dalam bahasa Melayu sebagai bahasa pengantar bagi kemudahan pemahaman pengajaran dan pembelajaran. Memandangkan jumlah pelajar yang semakin ramai dan kekurangan bangunan sekolah, maka sesetengah tempat menjalankan pendidikan agamanya dengan menumpang bangunan sekolah Melayu atau sekolah Inggeris. Misalnya Sekolah Agama Bukit Zahrah, Johor Bahru telah menumpang di Sekolah Inggeris Bukit Zahrah pada sebelah petangnya (Kamdi Kamil, 2018).

Dari segi sistem pembelajaran yang dijalankan dari tahun 1918 hingga 1927, kelas yang dihadiri oleh para pelajar adalah dari Darjah Satu (1) hingga Darjah Lima (V). Mereka akan diberikan Sijil Tamat Persekolahan setelah menamatkan pengajian pada Darjah Lima. Perubahan terus dilakukan disebabkan keperluan terhadap pendidikan agama semakin meningkat pada 1927. Sejak 1927, sekolah agama diletakkan di bawah tanggungjawab Penguasa Pelajaran Negeri dan selepas perang Dunia II pula diserahkan kepada Jabatan Agama Islam Johor. Semua SAPKJ ditingkatkan pengajian setahun lagi dengan mengadakan darjah enam (VI) dan mendapat Sijil Tamat Persekolahan darjah VI SAPJK.

Pemisahan yang dilakukan di antara Bahagian Pelajaran Inggeris dan Bahagian Pelajaran Melayu yang dibuat pada 1918 tidak kekal lama dan disatukan semula pada 1 Mac 1928 di bawah H.A.R Cheeseman selaku Penguasa Pelajaran (Superintendent of Education). Beliau telah menyusun semula sistem pendidikan di Johor termasuk menyelia pentadbiran dan pengurusan sekolah agama di Johor. Memandangkan Cheeseman bukanlah individu yang berpengetahuan dalam pendidikan agama, maka sebuah Jemaah Jawatankuasa Pelajaran Agama ditubuhkan bagi melicinkan perjalanan sekolah agama di Johor dengan diketuai oleh Yang Dipertua Jabatan Agama Johor selaku pengerusinya dan disertai pula oleh antaranya Timbalan Menteri Besar, Mufti Johor dan Kadi Besar Johor. Jawatankuasa ini bertanggungjawab mengurus pelbagai perkara seperti pentadbiran dan penubuhan sekolah agama dan Arab selain menguruskan pengambilan guru, peperiksaan, masalah guru, sukatan pelajaran dan kitab-kitab yang digunakan di sekolah. Selain Jawatankuasa Pelajaran Agama Johor, Majlis Agama Johor juga turut mengurus pentadbiran sekolah agama negeri selain urusan lain melibatkan hal-hal keagamaan negeri Johor (Kamdi Kamil, 2018).

Ketika ini pendidikan agama menjadi satu keperluan dan semakin penting. Oleh itu, kerajaan negeri telah menambah tempoh pengajian sehingga Darjah Enam (IV) pada tahun 1929. Selain itu, dalam memperkasakan lagi sistem pendidikan agama ke tahap yang lebih tinggi, kerajaan telah membuat perubahan lagi pada 1930 dengan memperkenalkan Darjah Khas Sekolah Agama Johor bagi mereka yang lulus Darjah Enam (Kamdi Kamil, 2018). Darjah Khas ini merupakan asas latihan perguruan guruguru sekolah agama. 
Secara umumnya sekolah-sekolah agama begitu pesat membangun di daerah-daerah seperti Johor Bahru selain Muar dan Batu Pahat di antara tahun 1929 hingga 1933. Para pelajar mempelajari matapelajaran Aqidah, Quran, Tajwid, Ibadat, Muamalat, Munakahat, Tawarikh, Adab, Tasawuf dan Jinayat mengikut tahap pelajar dari darjah 1 hingga 6 (Penyata Sekolah-sekolah Agama Johor dan Daerahnya bagi Tahun 1939; Kamdi Kamil, 2018). Antara yang lulus Darjah Enam dan Darjah Khas SAKJ ialah Mohamed bin Hamzah yang mengikuti pendidikan di Sekolah Agama Bukit Zahrah, Johor Bahru antara tahun 1928 hingga 1934. Selain sekolah agama, beliau juga telah memasuki Sekolah Inggeris Bukit Zahrah Johor Bahru antara tahun 1925 hingga 1930 (Kamdi Kamil, 2018).

Jadual 4: Jumlah Sekolah, Guru dan Pelajar Lelaki \& Perempuan Sekolah Agama di Johor Bahru, 1935- 1936. (Sumber: Diubahsuai daripada Penyata Jabatan Agama Johor, 1935 dan 1936)

\begin{tabular}{|c|c|c|c|c|c|c|}
\hline \multirow{2}{*}{ 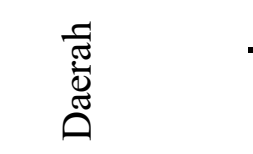 } & \multicolumn{3}{|c|}{1935} & \multicolumn{3}{|c|}{1936} \\
\hline & $\begin{array}{l}\text { Sekolah } \\
\text { Lelaki }\end{array}$ & $\begin{array}{l}\text { Guru } \\
\text { Lelaki }\end{array}$ & $\begin{array}{l}\text { Pelajar } \\
\text { Lelaki }\end{array}$ & $\begin{array}{l}\text { Sekolah } \\
\text { Lelaki }\end{array}$ & $\begin{array}{l}\text { Guru } \\
\text { Lelaki }\end{array}$ & $\begin{array}{l}\text { Pelajar } \\
\text { Lelaki }\end{array}$ \\
\hline 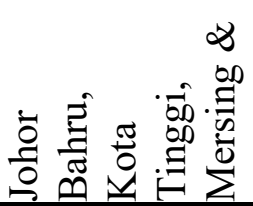 & 14 & 23 & 1262 & 15 & 27 & 1292 \\
\hline
\end{tabular}

\begin{tabular}{|c|c|c|c|c|c|c|}
\hline \multirow{3}{*}{ 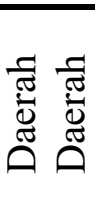 } & \multicolumn{3}{|c|}{1935} & \multicolumn{3}{|c|}{1936} \\
\hline & Sekolah & Guru & Pelajar & Sekolah & Guru & Pelajar \\
\hline & $\begin{array}{l}\text { Perempua } \\
\mathrm{n}\end{array}$ & $\begin{array}{l}\text { Perempua } \\
\mathrm{n}\end{array}$ & $\begin{array}{l}\text { Perempua } \\
\mathrm{n}\end{array}$ & $\begin{array}{l}\text { Perempua } \\
\mathrm{n}\end{array}$ & $\begin{array}{l}\text { Perempua } \\
\mathrm{n}\end{array}$ & $\begin{array}{l}\text { Perempua } \\
\mathrm{n}\end{array}$ \\
\hline & 3 & 6 & 164 & 4 & 6 & 192 \\
\hline
\end{tabular}

竞:

Peringkat awal keutamaan diberikan kepada pelajar lelaki, namun pada awal 1930-an, pendidikan agama bagi perempuan turut diberi perhatian. Oleh itu, terdapat 63 buah sekolah agama lelaki dan 7 buah sekolah agama perempuan di Johor. Daripada data Penyata Jabatan Agama Johor 1935 dan 1936, jumlah sekolah agama, jumlah guru dan pelajar lelaki di daerah Johor Bahru tidak diasingkan tetapi dicampur bersama daerah Kota Tinggi, Mersing dan Kluang. Hanya jumlah sekolah agama perempuan sahaja diasingkan bagi daerah Johor Bahru. Daripada data tersebut, kelihatan terdapat peningkatan dari segi jumlah sekolah, guru dan pelajar sama ada lelaki mahupun perempuan bagi kedua-dua tahun tersebut di daerah Johor Bahru.

Semenjak tahun 1938, telah diadakan kelas guru-guru pasukan (penyelia) agama di Johor Bahru selama seminggu pada akhir tahun tersebut. Kelas ini telah diajar oleh pemeriksa sekolah-sekolah agama Johor dan intipatinya ialah mengenai perkara atau 
kemusykilan agama yang terdapat dalam kitab-kitab dan juga mengenai peraturan serta kaedah mengajar yang terdapat dalam kitab pedoman mengajar. Bagi memantapkan ilmu pengetahuan agama, kelas hari Sabtu telah diadakan di Johor bagi guru-guru agama. Pembelajaran pada setiap hari Sabtu ini diberikan oleh guru-guru pasukannya kecuali di daerah Johor Bahru yang mendapat pembelajaran daripada guru besar Sekolah Agama Air Molek sendiri. Waktu kelas tersebut bermula pada jam 8.30 pagi hingga 1 petang. Mereka yang telah menyelesaikan kelas tersebut akan menduduki peperiksaan yang diadakan pada setiap hujung tahun oleh pemeriksa sekolah-sekolah agama. Bagi mereka yang lulus dengan markah $75 \%$ ke atas, mereka tidak lagi perlu mengambil peperiksaan dalam matapelajaran yang telah lulus tersebut. Walaupun kelihatan markah lulus adalah rendah, namun jumlah mereka yang lulus dalam peperiksaan adalah rendah, Misalnya pada tahun 1939, peperiksaan Tauhid telah dijalankan dan hanya 17 orang sahaja yang telah lulus dalam peperiksaan tersebut. Dua daripadanya adalah daripada Johor Bahru iaitu Abdul Ghani bin Haji Saad dan Ahmad bin Tani (Penyata Sekolah-Sekolah Agama Johor dan Daerahnya bagi Tahun 1939).

Selain itu terdapat juga Kelas Darjah Khas Sekolah Agama di Johor termasuk di Johor Bahru. Murid-murid darjah IV yang telah lulus akan diajar dalam darjah khas oleh guru yang dipilih oleh pemeriksa sekolah-sekolah agama. Ramai murid yang berjaya dalam mendalami ilmu agama dan mereka yang telah lulus darjah khas pada tahun 1938 akan menduduki peperiksaan yang dijalankan oleh Jabatan Agama Islam. Pada 1939, kurikulumnya telah digubal dengan mengkhusus kepada ilmu pengetahuan dan pendidikan Islam. Matapelajarannya ialah Tauhid (Akidah), Ibadat dan Quran. Aktiviti kokurikulum turut diadakan sejak 1939 seperti pertandingan syarahan dan berzanji, membaca dan menghafal al-Quran, menjayakan sambutan Maulidur Rasul dan Awal Muharam dan sebagainya (Kamdi Kamil, 2018).

Pada tahun 1939, murid-murid darjah khas yang menduduki peperiksaan di Johor adalah seramai 234 orang tetapi hanya 111 orang yang telah lulus dalam peperiksaan kelas darjah khas. Dalam konteks Johor Bahru, seramai 19 orang pelajar yang menduduki peperiksaan tetapi 11 orang sahaja yang telah lulus dan salah seorangnya ialah pelajar perempuan Sekolah Agama Air Molek. Pada akhir tahun 1939, seramai 9333 murid daripada darjah I hingga darjah IV telah menduduki peperiksaan dan 6833 murid telah lulus dengan peratus kepandaian $75 \%$ di seluruh negeri Johor. Daripada jumlah tersebut, seramai 651 orang murid dari daerah Johor Bahru telah menduduki peperiksaan dan 277 daripadanya telah telah lulus dengan peratus sebanyak 43\%. Peratusan lulus bagi pelajar di Johor Bahru adalah antara yang terrendah berbanding para pelajar daripada daerah lain di Johor seperti daerah Segamat (81\%), Muar (74\%), Batu Pahat (79\%). Bagi yang berjaya dalam peperiksaan, mereka akan dipilih untuk menjadi guru pelatih peringkat VI di sekolah-sekolah agama kerajaan Johor. Misalnya yang pada 1938, Abu Talib b. Abd. Rahman telah berjaya menjadi guru pelatih di daerah Johor Bahru. Sehingga 1939, bilangan guru agama yang mengajar di sekolah agama laki-laki berjumlah 174 keseluruhannya. Seramai 32 orang yang berpangkat II, 78 orang berpangkat III dan 39 orang pangkat IV ataupun pelatih manakala 25 murid 
darjah khas mendapat elaun kerana membantu dalam pengajaran. Terdapat seorang guru yang dilantik menjadi guru besar khas di Sekolah Agama Air Molek, Johor Bahru dan seorang lagi yang menjadi kerani pejabat pelajaran agama (Penyata, SekolahSekolah Agama Johor dan Daerahnya bagi Tahun 1939).

Pendudukan Jepun menyebabkan pada tahun 1941-1945 menyebabkan sekolah agama terpaksa dihentikan dan bahasa Jepun telah dijadikan matapelajaran tambahan di sekolah-sekolah Melayu. Terdapat beberapa daerah yang sekolahnya dibuka pada tahun 1945 seperti di Johor Bahru, Muar, Segamat, Pontian, Kota Tinggi dan Mersing. Pada 1947, sukatan baru SAKJ telah digubal lagi tetapi secara terperinci untuk memudahkan pengajaran seperti latihan mengambil wuduk dan solat fardu, ilmu kesihatan (untuk murid perempuan sahaja), latihan fardu kifayah (solat berjemaah dan pengurusan jenazah), ilmu faraid, pengetahuan am dan sebagainya. Sekitar 1953, sukatan pelajaran tahun sebelumnya telah dimansuhkan lalu diganti dengan matapelajaran Tauhid, Tafsir, Permulaan Adab, Tarikh, Bahasa Arab, Ibadat, Tajwid, Tasawuf. Sukatan pelajaran 1953 yang dikenali sebagai sukatan generasi kedua ini telah digunakan sehingga tahun 1995 dengan menggunakan kitab yang sama (Kamdi Kamil, 2018).

Sehingga tahun 1951, jumlah guru dan murid sama ada lelaki dan perempuan di sekolah agama di Johor Bahru terus meningkat. Ketika ini, pelajaran agama Johor diletakkan di bawah kelolaan dan pentadbiran Yang diPertua Jabatan Agama Johor. Beliau dipertanggungjawabkan untuk mengurus tiga buah cawangannya di Johor Bahru, Muar dan Batu Pahat. Tiap-tiap satu cawangan dijaga oleh dua orang Penolong Pemeriksa lelaki bagi sekolah-sekolah agama laki-laki dan perempuan bagi sekolah-sekolah agama perempuan serta tujuh orang guru pasukan iaitu di bahagian Johor Bahru, Johor Selatan, Kota Tinggi, Mersing dan Pontian, bahagian Johor Tengah, Batu Pahat serta Kluang dan bahagian Johor Utara, Muar, Tangkak dan Segamat. Kesemuanya telah diketuai oleh seorang pemeriksa sekolah-sekolah agama yang beribu pejabat di Johor Bahru (Penyata Sekolah-Sekolah Agama Johor dan Daerahnya bagi Tahun 1951).

\section{Peranan Pelbagai Pihak dalam Memajukan Pendidikan di Johor Bahru}

Pelbagai pihak telah memainkan peranan dalam memaju dan memperkasakan pendidikan awal di Johor Bahru. Mereka yang berperanan adalah yang mempunyai kesedaran yang tinggi terhadap kepentingan pendidikan dan berusaha untuk merubah kedudukan masyarakat Melayu supaya tidak ketinggalan dalam arus pembangunan ketika itu. Antara mereka yang telah berperanan adalah dalam kalangan raja-raja Melayu, golongan pentadbir Melayu yang terdiri daripada kalangan Penghulu dan Pegawai Daerah, golongan berpendidikan Melayu dan agama yang berusaha memartabatkan pendidikan masyarakat Melayu di Johor. Selain istana, terdapat juga usaha-usaha yang telah dilakukan untuk memberikan pendidikan dalam kalangan masyarakat ialah melalui pengajian agama di rumah-rumah, masjid-masjid, surausurau, pondok-pondok atau rumah guru agama sendiri. 


\section{Peranan Pemerintah}

Pemerintah Johor telah memainkan peranan dalam perkembangan pendidikan di Johor. Pada awal abad ke-19, Temenggung Ibrahim yang bermastautin di Teluk Belanga Singapura menyedari kepentingan pendidikan dan menyambut baik pengenalan sistem pendidikan oleh kerajaan British di Negeri Selat. Baginda berhasrat menyediakan sistem pendidikan yang disusun secara lebih teratur untuk anak-anak Johor. Baginda juga turut menyumbang $\$ 500$ setahun untuk sebuah sekolah bagi mengajar Bahasa Melayu selain menyediakan sebidang tanah untuk membina sekolah di Teluk Belanga. Melalui sumbangan tersebut terbinanya dua buah sekolah vernakular Melayu di Kampung Gelam pada 1840 dan Teluk Belanga Singapura pada 1846 (Rahimah Abdul Aziz \& Rahmat Saripan, 2002). Walaupun kedua-dua buah sekolah ini berada di Singapura, namun anak-anak Johor diberi peluang memasuki sekolah ini.

Pada tahun 1855, kerabat diraja Johor telah memainkan peranan dalam penubuhan Sekolah Perempuan Melayu yang pertama di Teluk Belanga Singapura (Manderson, 1990). Ini bertujuan untuk menggalakkan lebih ramai murid perempuan mendapat pendidikan selain memberi kesedaran kepada ibubapa tentang kepentingan pendidikan kepada anak lelaki mahupun perempuan. Temenggung Johor telah bersetuju untuk menyumbang sebanyak $\$ 1500$ bagi membolehkan sebuah Sekolah Perempuan Melayu dibuka di Teluk Belanga Singapura. Tindakan ini diambil apabila kerajaan British di India enggan memberikan peruntukan untuk menubuhkan sekolah-sekolah Melayu khususnya di NNS (Chelliah, 1947).

Selain Temenggung Ibrahim, Sultan Abu Bakar yang dikenali sebagai pengasas Johor moden merupakan antara sultan yang banyak membangunkan Johor. Antara sumbangan besar yang telah dilakukan adalah membawa perubahan Teluk Belanga, Singapura ke Tanjung Puteri dan akhirnya ditukarkan nama menjadi Johor Bahru pada tahun 1866 (Abd. Jalil Borham, 2002). Pada mulanya Maharaja Abu Bakar telah mengasaskan pendidikan sekular iaitu Tanjung Puteri School pada tahun 1864 yang merupakan sekolah rendah Inggeris pertama ditubuhkan di Johor. Sekolah ini kemudiannya dikenali sebagai Sekolah Johor Bahru pada tahun 1873 dan paderi H.G. Yzelman sebagai guru besarnya. Dua tahun kemudiannya sekolah ini dikenali sebagai Johor Free School dan bermula dari sekolah ini lahirlah lebih banyak sekolah Melayu, Inggeris dan sekolah vernakular lain di Johor Bahru. Selain itu, dibina juga English School Johor Bahru yang kemudiannya dikenali sebagai Sekolah Bukit Zahrah pada 1892. Sekolah Inggeris ini menggunakan sistem pendidikan Anglo-vernakular iaitu mengajar dalam Bahasa Melayu dan Inggeris (Sejarah Sekolah-sekolah Johor, tanpa tahun). Walaupun pemodenan berlaku di Johor, namun segala urusan pentadbiran dan hukuman negeri adalah berlandaskan undang-undang Islam serta undang-undang Inggeris yang tidak menyimpang daripada ajaran Islam.

Usaha untuk memajukan lagi pendidikan di negeri Johor dilihat tidak terhenti hanya setakat itu sahaja apabila Maharaja Abu Bakar bersetuju untuk menjadikan sebahagian daripada bangunan istana Teluk Belanga sebagai Sekolah Melayu peringkat tinggi, 
iaitu darjah lima dan enam. Sekolah ini dikenali juga dengan nama Malay College dan keseluruhan muridnya adalah seramai 40 orang. Maktab ini sebenarnya adalah lanjutan daripada Sekolah Melayu Teluk Belanga yang ada hanya setakat darjah empat sahaja (Khoo Kay Kim \& Mohd. Fadzil Othman, 1980). Kemudian, sebuah institut untuk melatih guru telah ditempatkan di maktab tersebut pada bulan Mac 1878. Pada 1887, sekolah perempuan Teluk Belanga terpaksa ditutup kerana kemerosotan bilangan muridnya. Oleh itu, baginda mencadangkan kediaman ibu saudara baginda iaitu Yang Mulia Ungku Besar digunakan sebagai Kolej Melayu dengan menyediakan ruangan untuk keperluan pendidikan bagi puteri kerabat diraja. Ini kerana menjadi tradisi masyarakat Melayu ketika itu melarang anak perempuan bebas keluar dikhalayak ramai. Oleh itu, sekolah ini memudahkan murid perempuan dalam kalangan kerabat diraja mendapatkan pendidikan secara formal (Sejarah Sekolah-sekolah Johor, tanpa tahun). Namun, percubaan tersebut mengalami kegagalan atas beberapa faktor seperti serangan penyakit beri-beri dan gaji guru yang rendah. Hal ini menyebabkan kerajaan di bawah pemerintahan Sultan Ibrahim terpaksa menubuhkan sebuah pusat latihan gurunya sendiri di Johor Bahru pada tahun 1906 dan diberi nama Johore Residential Malay Training College (M.A. Fawzi Basri, 1980). Walau bagaimanapun, maktab ini turut mengalami kemerosotan kerana kerajaan terpaksa menanggung kos pembiayaan yang tinggi dan terpaksa ditutup sehinggalah pada tahun 1928.

Selain itu, Maharaja Abu Bakar turut melakukan pembaharuan besar yang membantu masyarakat dalam bidang pendidikan formal tanpa mengenepikan perkembangan ilmu pengetahuan agama sedia ada yang telah pesat berkembang pesat di Johor. Baginda telah menyusun sekolah pengantar bahasa Melayu dan pendidikan agama bagi kemudahan anak-anak Melayu Johor. Dalam usaha menggalakkan masyarakat menghantar anak-anak ke sekolah Melayu, baginda turut menunjukkan contoh dengan menghantar anakanda baginda memasuki sekolah Melayu pada usia enam tahun sepertimana disebut oleh Mohd Said Sulaiman (1951) dalam karyanya Hikayat Johor:

"Bahawasanya adalah YAM seorang raja amat mengambil berat atas hal pelajaran. Paduka anakanda Tengku Mahkota pada masa usianya enam tahun telah mulai masuk belajar sekolah Melayu di Johor Bharu"

Gambar seterusnya merupakan gambar sekolah Melayu di Johor.

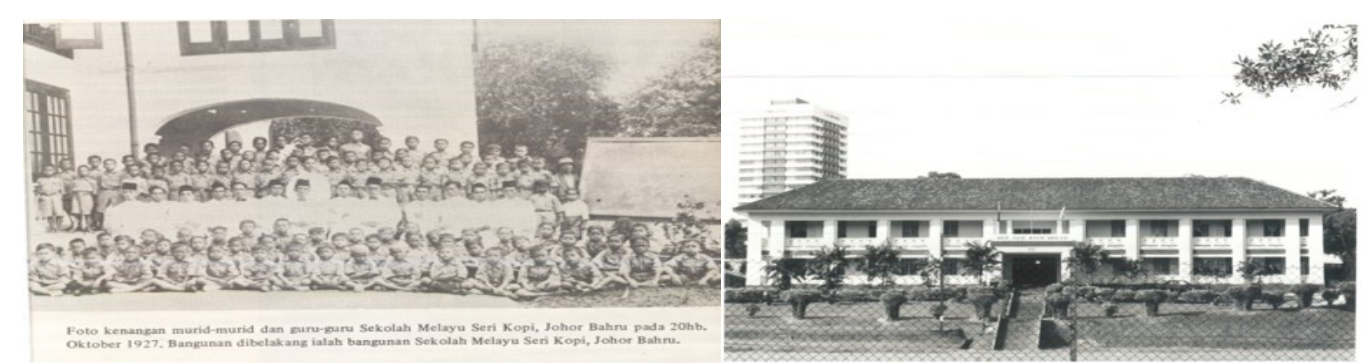

Rajah 2: Sekolah Melayu Seri Kopi Johor Bahru (gambar pertama) dan ditukar nama kepada Sekolah Melayu Air Molek (gambar kedua) (Sumber: Sejarah Sekolah-sekolah Johor, tanpa tahun; Arkib Negara Malaysia Cawangan Johor). 
Secara umumnya, peringkat awal pembinaan sekolah terutamanya sekolah Inggeris kurang mendapat sambutan daripada masyarakat Melayu kerana rata-rata ibubapa tidak mahu kehilangan tenaga kerja di rumah, sawah dan kebun. Mereka juga tidak mahu anak-anak mereka dikristiankan kerana sekolah Inggeris ditadbir oleh orang Eropah. Selain itu guru-guru agama membantah pembukaan sekolah vernakular kerana keadaan ini akan mengganggu keutuhan mereka dan mengancam kepentingan ekonomi mereka di samping sekolah vernakular ini tidak memperuntukkan pelajaran agama Islam kerana dasar British memisahkan pelajaran agama dengan pendidikan bahasa Melayu. Pelajar yang memasuki sekolah Melayu kebanyakannya adalah dalam kalangan kanakkanak lelaki dan mereka akan menamatkan pelajaran mereka di peringkat rendah sahaja iaitu sehingga darjah tiga atau empat sahaja. Hanya sebilangan mereka sahaja yang akan terpilih ke sekolah Inggeris. Hal ini menyebabkan pertambahan jumlah murid di Johor sangat lambat kecuali sekolah di daerah Johor Bahru. Misalnya Sekolah Bukit Zahrah mencatatkan 340 orang murid pada 1914. Oleh itu, para guru telah dihantar ke kampung untuk memberi kesedaran dan galakan kepada ibubapa untuk menghantar anak-anak ke sekolah (Sekolah-sekolah Johor, tanpa tahun). Memandangkan jumlah pelajar masih rendah, satu enakmen telah diperkenalkan pada 1902 dengan mewajibkan ibubapa menghantar anak-anak lelaki Melayu Johor yang berumur dari 7 hingga 16 tahun untuk ke sekolah. Jika mereka engkar, denda sebanyak \$25 atau dipenjara sehingga tiga bulan ke atas ibubapa tersebut, manakala anak mereka pula akan ditangkap dan dikenakan hukuman. Sultan Ibrahim juga bertitah supaya Persuruh Jaya, pegawai dan ketua kampung memainkan peranan untuk memberi kesedaran kepada masyarakat tentang kepentingan menuntut ilmu agama dalam kalangan kanak-kanak Islam di semua daerah Johor (Rahimah Abdul Aziz \& Rahmat Saripan, 2002).

Selain itu, tugas membangunkan pendidikan masyarakat Melayu turut dilakukan oleh Sultan Ibrahim. Sejak tahun 1895, beberapa buah sekolah telah dibina di Johor Bahru semasa zaman pemerintahan Sultan Ibrahim (Sekolah-sekolah Johor, tanpa tahun). Mohd Said Sulaiman (1951) yang merupakan Setiausaha Sulit kepada Sultan Ibrahim menyebut baginda juga sering menderma bukan sahaja untuk pembangunan sekolah aliran Inggeris tetapi juga sekolah agama di Singapura dan Johor sepertima kenyataan di bawah:

terutamanya bagi sekolah-sekolah (convent) yang di Singapura dan di Johor banyaklah beroleh pertolongan wang daripada YMM dari satu ke satu masa. Maka bukannya kerana percaya atas hal agama itu tetapi suka melihatkan pergerakan yang bersungguhsungguh berusaha mereka dengan tujuan hendak menjadikan berpelajaran dan berlaku baik bagi orang-orang dan kanak-kanak.

Di samping itu, Sultan Ibrahim juga turut menggalakkan masyarakat Melayu mendapatkan pendidikan dalam pelbagai aliran sama ada pendidikan Melayu atau Inggeris dan agama hingga ke peringkat tinggi di dalam mahu pun ke luar negara. Ini dapat dilihat melalui kenyataan Mohd Said Sulaiman, 1951: 
Adapun hal YAM tentang persekolahan anak-anak Johor daripada bangsa pun digalakkan sama ada pelajaran Melayu Inggeris Cina Keling dan juga apa-apa pelajaran berkenaan dengan agama Islam seperti belajar Quran belajar kitab belajar bahasa Arab sekaliannya dirancakkan bukannya sahaja tentang pelajaran yang rendah tetapi pelajaran yang tinggi jua seperti belajar dalam kolej-kolej dan pergi menuntut ke negeri asing jua sama ada ke sebelah Hong Kong India Mekah Mesir di Tanah Syam apatah lagi dalam England.

Sultan Ibrahim juga turut memberi tajaan bagi anak Melayu yang ingin menyambung pelajaran selain menggesa para pembesar dan orang kaya untuk memberi bantuan dari segi kewangan mahupun tenaga selain galakan bergotong royong bagi membina lebih banyak sekolah rakyat di sekitar Johor Bharu. Enekmen 1902 turut diperkenalkan bagi memastikan anak Melayu tidak ketinggalan dalam pendidikan (Sejarah Sekolahsekolah Johor, tanpa tahun). Selain menggalakkan anak Melayu ke sekolah Inggeris dan Melayu, baginda juga mewajibkan pendaftaran anak Melayu ke sekolah agama semasa era pemerintahannya dan hal ini membawa kepada peningkatan jumlah murid sekolah ketika itu (Kamdi Kamil, 2018). Melihat keadaan pertambahan tersebut, baginda telah menitahkan lebih banyak sekolah dibina dan sehingga 1941 terdapat 163 buah sekolah Melayu di Johor (Rahimah Abdul Aziz \& Rahmat Saripan, 2002). Bilangan sekolah yang dibina antara tahun 1946-1957 di Johor Bahru ialah 24 bua (Sejarah Sekolah-sekolah Johor, tanpa tahun). Ketika ini pelajaran agama telah diasingkan dari pendidikan Melayu di mana pelajaran Melayu diajar di sebelah pagi manakala pelajaran agama diajar pada sebelah petang. Walaupun perkembangan sekolah agama dan Melayu tergendala sewaktu zaman pendudukan Jepun, namun selepas perang, terdapat lima buah sekolah di buka di Johor Bahru termasuk beberapa sekolah di daerah-daerah lain (Kamdi Kamil, 2018).

\section{Peranan Pentadbir, Guru Melayu dan Penduduk Tempatan}

Selain pemerintah, pentadbir kerajaan dan para guru turut memainkan peranan dalam memastikan pendidikan diberikan kepada masyarakat. Ini dapat dilihat melalui usaha Datuk Bentara Dalam Muhammad Ibrahim bin Munsyi Abdullah yang sebelum itu menjadi guru di sekolah Melayu Teluk Belanga untuk menumpukan khidmat dalam pentadbiran di Johor sehingga dilantik sebagai Setiausaha Kerajaan. Beliau yang menetap di Jalan Air Molek Johor Bahru pada awal 1880-an merupakan seorang birokrat yang berjaya dalam bidang pendidikan Melayu apabila mencetuskan idea pengembangan pelajaran di Johor dan menjadi penasihat kepada Maharaja Abu Bakar dalam hal tersebut. Beliau mengambil inisiatif untuk memperkasakan lagi pendidikan Melayu setelah melihat kelembapan pertumbuhan sekolah Melayu dan idea memajukannya dipersetujui oleh baginda. Apabila Jabatan Pelajaran Johor dibentuk pada 1883, beliau telah ditugaskan sebagai Ketua Jabatan untuk mengelola dan memperkembangkan persekolahan dengan dibantu oleh Syed Alwi al-Kudsi sebagai Kerani Besar untuk menyatukan sistem pelajaran am Johor. Di saat negeri lain masih 
belum mempunyai sekolah Melayu atau hanya terdapat sebuah sekolah sahaja, Ibrahim Munsyi telah berjaya menubuhkan empat buah sekolah Melayu termasuk Sekolah Melayu Johor Bahru dan kesemua sekolah ini telah diletakkan di bawah pengawasan Jabatan Pelajaran (M. A. Fawzi Basri, 1978).

Dalam usaha untuk mengelola dan memajukan pendidikan di Johor Bahru, Ibrahim Munsyi meminta supaya Maharaja Abu Bakar menukarkan abangnya, Muhammad Khalid sebagai Guru Besar Sekolah Melayu di Johor Bahru pada 1880 berbanding tugasnya sebagai Penolong Ketua Jabatan Cetak kerajaan Johor di Singapura. Muhammad Khalid telah memulakan semula pelajaran Sekolah Melayu dengan membuka semula Sekolah Melayu Kampong Kandang Ayam di kawasan Istana Besar Johor. Selain menjadi Guru Besar Sekolah Melayu di Johor Bahru, Mohd. Khalid turut dilantik sebagai Guru Pelawat dan kemudiannya menjadi Setiausaha Jabatan Pelajaran dan Jawatankuasa Pelajaran Negeri. Beliau merupakan individu yang mengelola pentadbiran jabatan ini dengan dibantu oleh Ismail Mohammad selaku guru pelawat serta Ahmad Hashim sebagai keraninya. Mereka inilah yang berfungsi bagi memeriksa dan menubuhkan sekolah-sekolah di negeri Johor setelah Ibrahim Munsyi meninggal dunia dengan dibantu oleh W.W. Gawler yang berkhidmat sebagai Superintendent of School dalam Jabatan Pelajaran Johor pada tahun 1894. Tugas W.W. Gawler adalah untuk menjaga hal ehwal sekolah-sekolah Inggeris di Johor dan ternyata dapat melicinkan lagi pentadbiran Jabatan Pelajaran ketika itu (M.A. Fawzi Basri, 1980).

Setelah Jabatan Pelajaran Johor dirombak pada 1887, berlaku penyusunan pentadbiran dengan diketuai oleh Datuk Bentara Dalam dengan dibantu oleh 12 ahli jawatankuasa yang majoritinya adalah pentadbir Melayu (Kamdi Kamil,2018). Selain itu, beberapa buah sekolah telah dibina di beberapa buah daerah di bawah pentadbiran Dato' Bentara Alam. Kebanyakan bangunan sekolah dibuat sementara seperti menumpang di balai Penghulu, rumah pasung dan rumah ketua-ketua kampung. Kelihatan pembinaan sekolah Melayu di Johor mempunyai dua corak iaitu yang diasaskan oleh kerajaan dan yang didirikan oleh penduduk kampung secara gotong-royong (Sejarah Sekolahsekolah Johor, tanpa tahun). Walaupun demikian, sikap orang Melayu dalam memajukan pendidikan anak-anak sangat mendukacitakan lalu Ibrahim Munsyi mendesak supaya diwartakan 'Pendidikan Wajib' kepada kanak-kanak lelaki berumur tujuh tahun. Desakan beliau mendapat perhatian Maharaja Johor yang membawa kepada keluarnya 'Pemberitahuan Kerajaan'. Melalui Pemberitahuan Kerajaan yang telah ditandatangani pada 1 Jun 1902 menyebabkan wujud kesedaran para ibubapa berlakunya pertambahan sekolah-sekolah di merata tempat selain wujud sekolah Inggeris dan sekolah Arab di beberapa daerah seperti di Muar, Segamat dan Batu Pahat (M. A. Fawzi Basri,1978). Apabila sekolah-sekolah bertambah banyak, pentadbirannya dilakukan di Johor Bahru dan Muar. Sekolah Melayu Johor Bahru, Sekolah Inggeris Johor Bahru dan sekolah-sekolah di Tanjung Surat dan Johor Kampung diletakkan terus di bawah pentadbiran Munsyi Mohd Khalid yang merupakan Penguasa Pelajaran dari Pejabat Pelajaran Johor Bahru. Pada 1913, struktur pentadbiran Jabatan Pelajaran Johor diterajui oleh kebanyakannya pentadbir Melayu di mana Dato' Mohamed bin 
Mahbob merupakan Presidennya dan Inspektor bagi sekolah-sekolah di Johor Bahru diamanahkan kepada Encik Abu Bakar bin Hussain. Pada 1918, struktur pentadbiran sekolah telah berubah dimana Guru Pelawat di daerah Johor Bahru ialah Encik Mohd Doon bin Taib (Sejarah Sekolah-sekolah Johor, tanpa tahun).

Selain sekolah untuk murid lelaki, Ibrahim Munsyi telah mencadangkan supaya menubuhkan sekolah perempuan agar kanak-kanak perempuan turut diberi pendidikan setara dengan kanak-kanak lelaki. Berkat usahanya Sekolah Perempuan Melayu Johor Bahru telah dapat dibina pada 1918 dan Cik Hasnah binti Muhamad telah dilantik menjadi guru besar pada tahun tersebut. Sekolah ini pada mulanya bertempat di rumah Engku Sulaiman di Jalan Trus Johor Bahru kemudian berpindah ke Jalan Ayer Molek bersebelahan dengan Maktab Perguruan Melayu. Setelah bangunan tetap dibina, maka sekolah yang berada di Jalan Ngee Heng berpindah pada tahun 1924 dengan nama Sekolah Perempuan Bandar Tinggi, Johor Bahru. Sekolah ini pernah juga dijadikan pusat penempatan orang-orang yang mencari perlindungan dari daerah Mersing (Sejarah Sekolah-sekolah Johor, tanpa tahun).

Selain itu, terdapat juga tokoh agama yang memainkan peranan dalam memperkasakan pendidikan Islam di Johor. Misalnya Syed 'Alwi bin Tahir al-Haddad yang merupakan mufti yang mengetuai pentadbiran agama Johor dan Pengerusi Jawatankuasa Pemeriksa Kitab-kitab Sekolah Agama pada zaman Sultan Ibrahim telah membuat perubahan dengan menyelaras sistem pembelajaran dan pengajaran kitab-kitab yang digunakan di sekolah-sekolah agama Johor. Selain itu, beliau yang merupakan Pengerusi Jawatankuasa Penasihat Sekolah-sekolah Arab juga telah berperanan sebagai peneraju dalam menjana bantuan dan kewangan persekolahan dan peraturan sekolahsekolah Arab di seluruh negeri Johor. Beliau begitu menekankan tentang disiplin guruguru selain penerapan sahsiah dan kelulusan akademik. Manakala pembangunan sahsiah pelajar pula diaplikasikan melalui sukatan pelajaran yang sistematik merangkumi ilmu nahu, sarf, fiqh, hisab, mutalaah wa mahfuzah, Imla', Mubadi' akhlak, tarikh, geografi, insya', mubtadi' al-ulum dan tadbir al-sikhah. Orientasi pendidikan yang diperkenalkan ini bukan sahaja telah memberi perubahan dalam tradisi pendidikan agama di Johor malah memberi idea baru kepada pentadbir agama di negeri-negeri lain di Tanah Melayu (Farid Mat Zain \& Nurulwahidah Fauzi, 2014).

Dalam hal memajukan sekolah perempuan pula, terdapat peranan yang dimainkan oleh para guru wanita dalam mengasaskan sekolah perempuan untuk menggalakkan kanakkanak perempuan mendapatkan pendidikan ketika itu Hal ini dapat dilihat melalui usaha Cik Aminah binti Mohd Yassin yang mengasaskan Sekolah Perempuan Kampung Bahru, Johor Bahru pada 1922 dan beliau kemudiannya telah dilantik menjadi guru besarnya ketika itu. Kemudian sekolah perempuan lain turut didirikan pada tahun 1928 iaitu Sekolah Perempuan Bukit Senyum, Johor Bahru dan Cik Kalthom binti Ismail telah dilantik sebagai guru besarnya. Ketika ini, sekolah perempuan mengalami masalah dari segi kekurangan guru wanita. Untuk mengatasi masalah kekurangan tenaga pengajar, penyelia sains rumah tangga telah dilantik untuk 
mengajar murid-murid perempuan dalam pelajaran sains rumah tangga. Misalnya Ibu Azizah Jaafar yang merupakan adik kepada Dato' Onn Jaafar telah dilantik sebagai penyelia sains rumah tangga di Johor pada 1938. Azizah Jaafar berperanan dalam meluaskan lagi mata pelajaran tadbir rumahtangga dengan daya usahanya sendiri melalui penggunaan pelbagai jenis buku sains kesihatan dan urusan rumah tangga yang ditulis dalam bahasa Inggeris. Semua bahan bacaannya dikumpul dan diterjemah ke bahasa Melayu untuk dijadikan bahan pelajaran di sekolah tadbir rumah tangga. Sepertimana murid lelaki, murid perempuan telah diberi pendidikan asas bacaan, asuhan moral, pengetahuan am, kesihatan, malah ditambah dengan ilmu jahitan, pekerjaan tangan, masakan dan penjagaan kanak-kanak (Sejarah Sekolah-sekolah Johor, tanpa tahun).

Selain itu, Cik Zainun Sulaiman atau dikenali sebagai Ibu Zain juga turut memainkan peranan dalam menggalakkan ibubapa menghantar anak-anak perempuan mereka ke sekolah. Beliau yang dilantik sebagai Guru Pelawat Sekolah-sekolah Perempuan pada 1925 telah berusaha membawa perubahan minda bagi masyarakat Melayu dan menubuhkan persatuan Pandu Puteri (Girls Guide) di beberapa buah sekolah perempuan Johor untuk meningkatkan keyakinan diri dalam kalangan murid perempuan ketika itu (Arba'iyah Mohd Noor, 2020). Melalui galakan dan kesedaran yang diberikan oleh beliau telah menyebabkan sesetengah ibu bapa mula memberi perhatian terhadap pendidikan formal kepada anak-anak perempuan mereka. Ibu bapa merasakan bahawa anak-anak perempuan juga perlu diberi pendidikan formal sepertimana anak-anak lelaki untuk kesenangan masa hadapan mereka

\section{Kesimpulan}

Secara umumnya pendidikan agama dan Melayu di Johor telah melalui tempoh yang panjang melebihi 100 tahun. Dalam tempoh tersebut banyak perubahan yang telah dilakukan oleh pelbagai pihak dalam usaha memperkasakan kedua-dua sistem pendidikan tersebut. Jelas walaupun banyak sekolah Inggeris didirikan di Johor Bahru, namun pemerintah juga memberi perhatian terhadap sekolah Melayu dan sekolah agama selain meningkatkan kurikulumnya. Tujuannya adalah supaya masyarakat Melayu mempunyai kesedaran yang tinggi untuk memajukan pendidikan anak-anak mereka demi masa hadapan yang lebih cemerlang. Lulusan sekolah agama dan sekolah Melayu di Johor telah menyumbang kepada kefahaman Islam dalam kalangan rakyatnya terutama yang mendapat pendidikan di Johor Bahru. Mereka bukan sahaja cemerlang dalam bidang agama tetapi bidang lain seperti pendidikan, politik, pentadbiran, ekonomi, perubatan dan sebagainya. Malah ramai antara mereka menjadi tokoh hebat yang menyumbang bakti terhadap negeri Johor selepas negara mencapai kemerdekaan.

\section{Penghargaan}

Kami ingin mengucapkan penghargaan kepada pihak Universiti Malaya khususnya Fakulti Sastera dan Sains Sosial di atas sokongan terhadap penyelidikan di bawah geran RU Fakulti Program (GPF 016J-2018) serta orang perseorangan sama ada secara 
langsung atau tidak langsung dalam menyempurnakan penyelidikan dan penerbitan artikel ini.

\section{Rujukan}

\section{Sumber Primer}

Annual Report Johor, 1910.

Annual Report Johor, 1912.

Annual Report Johor, 1913.

Annual Report Johor, 1914.

Annual Report Johor, 1915.

Education in Johore, 1928-1933. printed by Government Printing Department Johore, Arkib Negara Malaysia Cawangan Johor.

Jabatan Pelajaran Johor. tanpa tahun. Sejarah Sekolah-sekolah Johor. Johor Bahru: Jabatan Pelajaran Johor.

Mohd Said Sulaiman, Hikayat Johor (kedua), Tawarikh YMM Ibrahim Sultan Johor: Dari permulaan hingga Kedatangan Jepun 1941, Johor: Pejabat Cetak Kerajaan, 1951 (jawi).

Penyata Jabatan Agama Johor, 1932.

Penyata Sekolah-sekolah Agama Johor dan Daerahnya bagi Tahun 1939.

Penyata Sekolah-Sekolah Agama Johor dan Daerahnya bagi Tahun 1951.

\section{Sumber Sekunder}

Abd. Jalil Borham. (2002). Pentadbiran Undang-undang Islam Negeri Johor, Johor: Universiti Teknologi Malaysia Skudai.

Arba'iyah Mohd Noor. (2020). "The Transition of Malay Women's Role And Contribution In The Early 20th Century", Journal of al-Tamaddun, Vol. 15 (1).

Chelliah, D.D. (1947). A Short History of the Education Policy of the Straits Settlements 1800 to 1925, Kuala Lumpur: The Government Press.

Farid Mat Zain \& Nurulwahidah Fauzi. (2014). "Ulama Arab di Tanah Melayu: Satu Analisa pada awal Abad ke-20", Religi, vol. X, No. 2, Julai.

Kamdi Kamil. (2018). Seratus Tahun Pendidikan Islam Negeri Johor Darul Takzim, Johor Bahru: Jabatan Agama Islam Negeri Johor.

M.A. Fawzi Basri. (1980). "Perkembangan Pendidikan di Negeri Johor 1856-1939: Satu Kajian Ringkas”, disusun oleh Khoo Kay Kim \& Mohd. Fadzil Othman, diselenggarakan oleh Jazamuddin Baharuddin, Pendidikan di Malaysia: Dahulu dan Sekarang, Kuala Lumpur: Persatuan Sejarah Malaysia.

Manderson Lenore. (1990). Wanita, Politik dan Perubahan, Siri Sains Sosial, Kuala Lumpur: Penerbit Fajar Bakti.

M. A. Fawzi Basri. (1978). "Perkembangan dan Peranan Jabatan Agama Johor 18951940" dalam Sejarah Johor Moden 1855-1940: Satu Perbincangan dari Pelbagai Aspek, Kuala Lumpur: Muzium Negara.

Rahimah Abdul Aziz \& Rahmat Saripan. (2002). Pendidikan: Asas Kemajuan Minda dan Material di Johor, Johor Bahru: Yayasan Warisan Johor. 